Review Article

\title{
Feed Additives Produced on the Basis of Organic Forms of Micronutrients as a Means of Biofortification of Food of Animal Origin
}

\author{
Wanda Górniak $\mathbb{D}^{1},{ }^{1}$ Paulina Cholewińska $\mathbb{D D}^{2},{ }^{2}$ and Damian Konkol $\mathbb{D}^{1}$ \\ ${ }^{1}$ Department of Environment, Hygiene and Animal Welfare, Wrockaw University of Environmental and Life Sciences, \\ Chelmońskiego 38C, 51-630 Wrocław, Poland \\ ${ }^{2}$ Institute of Animal Breeding, Wrocław University of Environmental and Life Sciences, Chełmońskiego 38C, \\ 61-630 Wrocław, Poland \\ Correspondence should be addressed to Damian Konkol; damian.konkol@upwr.edu.pl
}

Received 4 June 2018; Revised 29 June 2018; Accepted 10 July 2018; Published 1 August 2018

Academic Editor: Magdalena Jastrzębska

Copyright (c) 2018 Wanda Górniak et al. This is an open access article distributed under the Creative Commons Attribution License, which permits unrestricted use, distribution, and reproduction in any medium, provided the original work is properly cited.

\begin{abstract}
In recent years, there has been a steadily growing demand for animal protein. Consumer awareness is also growing every year, which is why breeders are obliged to provide animals with the best possible environmental conditions that will determine the productivity of animals and the quality of raw materials obtained from them. Today's consumer is looking for not only the highest quality food but also the one that will characterize health-promoting properties. Therefore, food is sought, which will be characterized by a favorable profile of fatty acids and a high content of biologically active ingredients, such as vitamins or minerals. One of the most effective methods of enriching food with these ingredients is their supplementation in feed. However, it should be remembered that the form in which such a component will be delivered is very important. High hopes are associated with the possibility of using organic forms of macro- and micronutrients, which are sometimes better absorbed than inorganic salts. The aim of the work was to collect and systematize knowledge related to the possibility of enriching food of animal origin with micronutrients using additional feed containing these ingredients in organic form.
\end{abstract}

\section{Introduction}

The performance of farm animals, their health, and the quality of raw materials obtained from them depend on two main factors. The first is the genotype of the animal and the second is the breeding environment. The basic components of the breeding environment are microclimatic conditions (well-being) and nutritional factors. Proper nutrition of farm animals and ensuring the best possible environmental conditions will determine the optimal growth and development of animals, the quality of animal products, and, consequently, production economics [1]. The constantly growing demand for animal protein ensures the stability of the market for animal products and the feed market. In 2015, the value of the global feed market amounted to USD 400 billion [2]. The largest feed production markets are the United States
(176 million tons), China (180 million tons), and the European Union (161 million tons) [3]. The structure of the global feed market is concentrated in five main directions, of which the most important is the production of feed for pigs, poultry, and cattle amounting to $31.8,33.7$, and $26.8 \%$ of global production. Due to the physiology of the digestive tract of livestock, the production of feed is mainly based on plantbased materials. Feed materials of the greatest strategic importance are cereals, soybeans, fats, meat, and bone meals as well as food industry waste [1].

In the production of complete compound feeds, feed additives are also very important. By definition, feed additives are chemical substances, mixtures thereof, and microorganisms other than feed materials and premixes, which have the characteristics of certain functionality. Feed additives are designed to supplement nutrient deficiencies, 
improve the taste of feed and its hygienisation, increase the use of feed, and stabilize the gastrointestinal microflora [4]. Feed additives are also used to obtain products of animal origin that will be characterized by a better taste and a higher content of biologically active compounds, such as micronutrients or polyunsaturated fatty acids [5]. This is so-called functional food.

\section{Functional Food}

Functional food is defined as food designed for the individual needs of the organism. It may have a nutraceutical character. Functional features can be obtained by modifying the composition of food, eliminating antinutritional ingredients, increasing the concentration of ingredients naturally present in food, and increasing the bioavailability of biologically active compounds [6]. Functional foods must also ensure consumer safety and must also cover consumer demand for nutrients. Functional food can be divided because of its composition and because of its effect on the human organism. In the first case, enriched, low-energy, probiotic, high-fiber, low-cholesterol, low-sodium, and other foods stand out. The second one includes food that reduces the risk of cardiovascular disease, reduces the risk of cancer, and reduces the risk of osteoporosis and food for the elderly, athletes, and people with metabolic and digestive disorders [7]. It should be noted that the global functional food market is developing very dynamically, which is caused by increasing knowledge about biologically active compounds, development of biotechnology, fashion for new types of food and their promotion, fashion for a healthy lifestyle, increased purchasing power of consumers, and aging of the society which is connected with the increase in the cost of medical care [1].

\section{The Physiological Role of Microelements}

Microelements are among the nutrients that play an important role in human nutrition because they are responsible for maintaining homeostasis of the organism. The microelements include elements such as iron, copper, iodine, zinc, manganese, selenium, and chromium.

Iron is an element necessary for the synthesis of hemoglobin and myoglobin. This element is also a component of enzymes found in erythrocytes and enzymes involved in the transfer of electrons in oxidation-reduction processes. The main disorder resulting from iron deficiency is anemia.

Copper is a component of antioxidant enzymes and occurs in peroxide dismutase, cytochrome c oxidase, and ceruloplasmin. It also takes part in the production of catecholamines and neuropeptides and is responsible for the synthesis of collagen. Copper deficiencies lower the activity of superoxide dismutase. Lowering the activity of this enzyme reduces the iron metabolism, which in turn leads to anemia. Copper deficiencies also cause poor growth, changes in the structure of the hair, dysfunctions of the nervous system, and dieback of embryos.

Iodine is an essential element in the synthesis of thyroid hormones-thyroxine, triiodothyronine, and tetraiodothyronine. Iodine deficiencies lead to hypothyroidism, hair loss, and cause abortions.
Zinc is present in all organs, tissues, and body fluids of the organism. This element is responsible for the stabilization of cell membranes, synthesis, and transformation of proteins, fats, and nucleic acids. It is an element necessary in growth processes and in gene expression. Zinc deficiencies lead to disturbances of cellular metabolism, synthesis of nucleic acids and proteins, lack of appetite, skin diseases, poor wound healing, and lower libido.

Manganese is an activator of numerous enzymes such as hepatic arginase, kinase, decarboxylase, hydrolase, and transferase. It participates in the metabolism of fats and carbohydrates and in the formation of proteins and cartilage. Manganese deficiencies lead to anomalies in the formation of the skeleton and osteoarticular system, weakening of the immune response and neurological reactions.

Selenium is an integral part of glutathione peroxidase, which has strong antioxidant properties. It also occurs in deiodinase 5-iodothyronine, which affects the immune response of the body. Selenium deficiencies can cause stomach ulcers, degeneration of the liver and kidneys, and cardiomyopathies.

Chromium as a factor of glucose tolerance is an element necessary for the action of insulin. It takes part in the synthesis of lipids and reduces the rate of fat deposition. Chromium participates in protein metabolism and synthesis of nucleic acids. This element occurs in the cell nuclei and mitochondria. Chromium deficiencies lower the effectiveness of insulin [8].

3.1. Enrichment of Eggs with Microelements. Egg is a product for which consumers eagerly reach because it is relatively cheap and has a high nutritional value. It is not surprising that consumers pay attention to the size of eggs, their freshness, cholesterol content, polyunsaturated fatty acids omega- 3 and omega-6, and minerals. The production of animal products with higher macro- and microelement content is becoming increasingly important, especially if we take into account the deficiency of minerals in the human diet that has been occurring for many years. It is estimated that this problem affects about 2 billion people [9]. The solution may be to enrich the food already at the level of animal husbandry through the use of feed additives that contain minerals with high bioavailability. The effectiveness of such methods is usually expressed as the level of inclusion of an ingredient in a product of animal origin [5, 10]. Therefore, in the feed industry and among breeders, there is an increasing interest in the possibility of using new materials such as algae enriched in microcomponents [11], fossil materials [12], food industry waste such as yeast [13], and other organic waste [5]. The appropriate content of macro- and microelements in compound feed is also necessary from the point of view of production economics because it will not only allow obtaining products with an increased content of these ingredients but also help to maintain the health and production parameters of animals at an optimal level [14]. When determining the composition of the feed ration or compound feed, it should be taken into account that the amount of minerals is often insufficient due to the different bioavailability of the elements and the presence of antinutritional compounds in the feed material [15]. The bioavailability of minerals is primarily 
influenced by the form in which they occur. In animal nutrition, microelements in the form of inorganic salts are usually used; however, it turns out that some microelements in organic form can be absorbed much better by animals [1] In recent years, many studies have been carried out on the possibility of enriching eggs with microelements using their organic forms.

Santoso and Fenita [16] examined the effect of the addition of katuk (Sauropus androgynus) leaf extract on the production parameters of laying hens and the quality parameters and chemical composition of eggs. Analysis of the results did not show the impact of the used additives on the production parameters of birds. The applied additives significantly $(p<0.05)$ improved the organoleptic characteristics of the eggs. However, it has not been shown that the addition of katuk leaf extract influenced the content of calcium, phosphorus, and iron in the egg. Other studies concerned the use of soybean meal enriched with microelements in the biosorption process in feeding of laying hens [17]. In this study, birds from the control group received copper, zinc, and iron in the form of inorganic salts. The experimental groups received these elements in the organic form, and the group receiving the addition of organic chromium was also formed. The analysis of the results showed a higher strength of egg shells obtained from hens receiving the addition of copper and chromium in the organic form and a more intensive color of egg yolks obtained from hens receiving the addition of copper and zinc in the organic form. Birds from experimental groups receiving the addition of chromium and copper were characterized by lower feed intake. The highest feed intake was observed in hens receiving iron in the organic form. The experiment was carried out in three series. Doses of micronutrients were established on the basis of nutritional standards [18]. In the control group, the demand for hens for micronutrients was covered in 100\% in all three series. The demand for the given microelement in experimental groups was covered in $100 \%, 150 \%$, and $200 \%$ during series I, II, and III, respectively, by enriched soybean meal. This treatment did not affect the eggs quality; however, birds receiving the addition of copper, chromium, and iron in the organic form were characterized by lower feed intake. Saeid et al. [19] showed that the use of Spirulina maxima algae enriched with microelements as a feed additive increases their content in the egg. Analysis of the results showed that the content of iron, zinc, and manganese in the egg white of hens receiving the addition of algae was higher by 860,113 , and $195 \%$, respectively. The used additive did not affect the feed conversion rate.

Opaliński et al. [20] showed that the use of yeast enriched with iodine in laying hens significantly increases the level of this element in the egg. In these studies, the birds were divided into three groups. The hens from the control group received iodine in inorganic form $(1 \mathrm{mg} / \mathrm{kg}$ of feed), and birds from experimental groups received the addition of yeast enriched with iodine in the amount of $1 \mathrm{mg}$ and $2 \mathrm{mg} / \mathrm{kg}$ of feed, respectively. The authors did not state that the applied additives influenced the production parameters; however, they noticed that higher doses of iodine had a negative effect on the intake and use of feed. The addition of iodine in organic form also improved the yolk color and increased the weight of eggs. It was also found that the additive used had a negative effect on the strength of the shell. The content of iodine in egg yolks from the experimental groups was higher by 80 and $90 \%$, respectively, compared to the control group.

Abedini et al. [21] studied the influence of various zinc sources on the production parameters of laying hens and egg quality. The authors divided the birds into four groups. In the control group, the zinc was not supplemented, and the experimental groups received zinc in the form of nanoparticles, zinc oxide, and zinc methionine. The results showed that the hens receiving zinc in the form of nanoparticles and zinc methionine were characterized by higher egg laying and the eggs composed by them with a higher mass. These groups were also characterized by a higher $(P<0.01)$ concentration of zinc in the tibia, liver, pancreas, and eggs. Magied et al. [22] also investigated the effect of various zinc forms on the production parameters of laying hens and on the content of zinc in eggs and tissues. They showed that the highest concentrations of zinc were found in eggs from hens receiving the addition of zinc methionine. The authors also found that birds from this group were characterized by the highest egg laying.

Venglovska et al. [23] investigated the influence of various manganese forms on the production parameters of laying hens and egg quality parameters. The birds were divided into 4 groups. In the control group, manganese was not supplemented, and the experimental groups received manganese in the form of sulphate, chelate from the protein hydrolyzate, and chelate from glycine hydrate. Supplementation of manganese did not affect the production parameters; however, it increased the strength of the shell. Hen eggs from the group received manganese in the form of chelate from glycine hydrate were characterized by a much higher concentration of this element in the yolk. It has also been shown that supplementation of organic forms of manganese extends the period of storage of eggs.

Brodacki et al. [24] divided birds into two groups. The first group did not receive any additives, while the second group received copper chelate in an amount $30 \mathrm{mg} \mathrm{Cu} \mathrm{L-1}$ with drinking water. Analysis of the results showed that the hens receiving the copper chelate supplement deposited heavier eggs, which were also characterized by a higher protein level. However, the authors did not show significant changes in the mineral composition of the analyzed eggs.

Tufarelli et al. [25] investigated the effect of 2-hydroxy-4methylselenobutanoic acid on the production parameters of laying hens and the selenium content in eggs. They showed that supplementation of this acid does not affect the production parameters of birds; however, it improves the profile of fatty acids in the egg yolk and increases the content of vitamin E. Analysis of the results also showed that egg yolks from hens fed 2-hydroxy-4-methylselenobutanoic acid were characterized by a significantly higher $(P<0.001)$ selenium content compared to those from hens whose feed was not supplemented. Chinrasri et al. [26] carried out the feeding experience on laying quails. The authors divided the birds into four groups. The control group did not receive any supplement, the second group received sodium selenite, the 
third received selenium yeast supplement, and the fourth received hydroponically produced selenium-enriched kale sprout (Brassica oleracea var. alboglabra L.). Analysis of the results showed that the use of various forms of selenium did not affect the production parameters of birds and egg quality parameters. It was also shown that the eggs of quails fed with the addition of hydroponically produced selenium-enriched kale sprout and selenium yeast were characterized by a higher $(P<0.05)$ selenium concentration than the eggs of other groups.

The study by Malathi [27] showed that supplementation of chromium yeast and nanochrome in the laying hens' diet increases egg production and improves their quality parameters. Chromium supplementation from both sources also increases the content of this element in the egg and reduces the content of fat and cholesterol.

3.2. Enrichment of Milk with Microelements. According to FAO estimates, global milk production will increase by $1.4 \%$ in 2017 and reach the value of 830 million tons [28]. The increase in production is linked to the high demand for dairy products (especially cheeses) in developing countries. The production structure shows that cow's milk is the most commonly consumed, followed by buffalo and sheep's milk. It should be noted that milk and milk products account for a large proportion of the functional products consumed in the human diet, but that their health benefits are still being verified.

The milk consists of three phases, emulsion, colloidal, and molecular, which are continuously integrated. The composition of the milk is a result of factors such as species, age, breed, individual characteristics, nutrition, maintenance, and health. On average, cow's milk contains water (approx. 88.5\%), dry matter (approx. 11.5\%), lactose (approx. 4.7\%), fat (approx. 3.7\%), and total protein (approx. 3.7\%). The composition and consumption value of milk and milk products can be adequately influenced by appropriate breeding programmes and by the impact on the farm environment [29].

In recent years, milk has been seen not only as a source of nutrients but also as a factor in human health and well-being. The milk contains many bioactive substances such as immunoglobulins, hormones, cytokinins, growth factors, polyamides, nucleotides, peptides, fats, fatty acids (monounsaturated and polyunsaturated), fat-soluble vitamins (e.g., $\mathrm{A}, \mathrm{E}$, and $\mathrm{K}$ ), carotenoids, and phospholipids $[1,30]$. The milk also contains minerals and salts of organic acids, which make up between 0.65 and $0.7 \%$ of the milk. These compounds go into milk from blood plasma. They participate in the stabilization of milk and in shaping its taste and catalyzing some of the reactions occurring in it. Milk is characterized by the highest variability in the level of micronutrients because their level depends on their content in the feed $[1,29]$.

Milk is responsible for the proper growth and development of juveniles, which is why they should provide them with all necessary nutrients, including micronutrients. Milk and milk products are an important source of minerals in many European countries, covering between 10 and 20\% of daily consumption. However, the content of trace elements in milk depends on their content in soil and feed for cattle, sheep, and goats, which varies greatly from one country to another. Their content may also be influenced by the pasteurization and sterilization process. Such milk processing means that their content in milk is slightly reduced. The exception is iron, the content of which is higher in consumer milk $[29,31]$.

The content of microelements in milk is also dependent on the species of the animal. Sheep milk contains a greater amount of micronutrients than cow's milk, which is also related to the ash content: $0.9 \%$ in sheep's milk and $0.7 \%$ in cow's milk. In addition, preparations such as hard sheep cheese contain high concentration of zinc, which is associated with its high content in milk $(415 \mu / 100 \mathrm{~g}$ in sheep's milk and $74-145 \mu / 100 \mathrm{~g}$ in cow's milk). However, cow's milk is characterized by the highest content of selenium (1.3-1.7 $\mu \mathrm{g} / 100 \mathrm{~g}$ in cow's milk, $0.9 \mu / 100 \mathrm{~g}$ in sheep's milk, and $0.7 \mu / 100 \mathrm{~g}$ in goat's milk) in comparison with sheep's and goat's milk [31].

In order to increase the bioavailability and to reduce differences in the content of micronutrients, inorganic and organic additives were used in the feed. However, recent studies have shown that the absorption and use of trace elements are greater when they are replenished in organic forms. Metalloproteins, polysaccharides, chelates, hydroxyanalogs, hydroxychlorides, and metal chelates such as $\mathrm{Zn}, \mathrm{Cu}, \mathrm{Fe}, \mathrm{Mn}$, and Co were developed to increase the absorption capacity and improve the bioavailability of micronutrients [1].

A study conducted by Witkowska et al. [32] where the carrier of micronutrients such as $\mathrm{Zn}(\mathrm{II}), \mathrm{Cu}(\mathrm{II}), \mathrm{Fe}(\mathrm{II}), \mathrm{Cr}$ (III), and $\mathrm{Mn}$ (II) was soy meal showed that the used biological additives led to the enrichment of goat's milk in copper (about $8.2 \%$ ), manganese (29.2\%), and zinc (14.6\%). In addition, the cheese from the experimental group was richer in $\mathrm{Zn}$ by $19.8 \%$ compared to the control group. It was found that the organic form of selenium is also better absorbed than the inorganic form. Naturally occurring organic selenium is represented by a mixture of selenic acid and selenomethionine. Absorption of selenomethionine takes place in a similar way to methionine absorption, thanks to which you can manipulate its content in the final product. However, it should be borne in mind that the selenium dosage should be chosen very careful because excess dosage (above $0.2-0.3 \mathrm{ppm}$ ) is toxic to the body. It is also possible to enrich milk in Se with tablets, in which the carriers are, for example, sea algae $[8,31,33,34]$. The carrier in the form of sea algae can also be used to enrich milk with iodine and cobalt. This is extremely important in the case of cobalt because many animals are fed with feed materials originating from alkaline soils, which hinders the absorption of this element by plants [8].

In addition, microelement supplementation with organic carriers improves the milk yield of cows and the minimum increase of fat and protein in milk. Supplementation with organic $\mathrm{Zn}, \mathrm{Mn}$, and $\mathrm{Cu}$ (from the amino acid complex) and Co (from cobalt glucoheptonate) improves productivity and is the cause of better hoof health. Supplementation of microelements in this form also reduces the concentration of ketone bodies and GGT in the blood [35]. 
Páleníková et al. [36] conducted studies on goats. They showed that the level of copper in the colostrum of goats receiving the addition of copper sulphate was significantly higher than that in the colostrum of goats receiving the addition of copper chelate. What is more, the kids born by goats receiving the addition of copper sulphate were characterized by higher birth weight. Their results suggest, therefore, that the inorganic form of copper is better absorbed than the organic one.

3.3. Enrichment of Meat with Microelements. Meat provides many valuable nutrients, which is why it is one of the basic raw materials of animal origin used in food production, and is the dominant part of every human diet. In western European diets, meat is a valuable source of protein, minerals (e.g., Fe, $\mathrm{Zn}, \mathrm{Se}, \mathrm{Cu}$ ), vitamins (e.g., vitamins $\mathrm{A}, \mathrm{B} 1, \mathrm{~B} 6$, and $\mathrm{B} 12$, riboflavin, folate, niacin, and pantothenic acid), and essential fatty acids [37]. In modern animal farms, a large emphasis is given to the quality of feed and bioavailability of ingredients necessary for proper development and growth of the organisms. Research on the content of micronutrients in meat mainly concerns the change in composition in pork, beef, and poultry, as they are consumed in the largest amounts [2].

Poultry meat is readily consumed around the world. Breasts and drumsticks with thighs are mostly eaten. White meat contains more potassium and magnesium and less iron and zinc compared to red meat. The poultry meat contains from $19 \%$ to $23 \%$ protein, $1.9 \%$ fat in breasts, and $4.7-6 \%$ in thigh muscles [38]. With the development of modern highyielding broiler chicken lines, the demand for trace elements in feed has increased [39]. The enrichment of poultry meat with functional ingredients and microelements is an added value and beneficial for human health. Sahraei et al. [40] evaluated the bioavailability of four zinc sources (zinc sulphate, two sources of zinc oxide, and Bioplex Zn composed of organic zinc compounds) for broilers fed the cornsoybean diet. Zinc sulphate was used as the criterion of bioavailability. It was found that Bioplex $\mathrm{Zn}$ containing organic zinc compounds was more available than zinc from other sources which could be used in the feed industry as an additional source in broiler rearing. Sobolev et al. [41] conducted experiments on the effect of adding various doses of selenium in compound feeds on its specificity and distribution in muscle tissues of various species of poultry. It was found that feeding broilers, young geese, and ducks with feeds containing selenium added increased the concentration of this microelement in the chest muscles, respectively, by $21.7-106.7 \%, 35.1-40.0 \%$, and $23.2-66.0 \%$, and the leg muscles by $13.0-85.7 \%, 57.4-61.7 \%$, and $20.5-79.4 \%$. Li et al. [42] conducted studies on the impact of various Se sources on the local Chinese Subei chickens. However, they did not show significant difference in feed intake and body weight gain. However, it was noticed that organic Se supplementation improved the antioxidant capacity and meat quality compared to the meat of chickens fed with the addition of inorganic Se.

Pork is a popular meat consumed all over the world and is also a source of high biological value protein. For this reason, many scientists are studying the impact of various dietary supplements on the properties and quality of this meat, searching for solutions to enrich the various micronutrients needed by the human body. Michalak et al. [43] studied the effect of Enteromorpha sp. enriched with $\mathrm{Zn}$ (II) and $\mathrm{Cu}(\mathrm{II})$ ions through the biosorption process on the mineral composition of meat. The experiment was conducted on two groups of growing pigs for 3 months. Both groups were fed the same feed mixtures that had the same basic nutrient content. The control group was fed with the addition of micronutrients with inorganic salts, while the experimental group enriched with macroalgae. From the basic mixture for the experimental group, the inorganic forms $\mathrm{Zn}$ and $\mathrm{Cu}$ were removed and replaced with enriched algae. The level of toxic elements in the diet with macroalgae was below the acceptable level. It was found that, in the meat of algae-fed pigs, the content of trace elements was higher ( $\mathrm{Mn}, 49 \%$; $\mathrm{Fe}, 13 \%$; $\mathrm{Cu}, 12 \%$; and $\mathrm{Zn}$, by only $4.0 \%$ ) than in the control group. From this, it follows that biological forms of micronutrients are more bioavailable to animals than inorganic forms and can be an alternative to inorganic mineral salts.

Experiment done by Saeid et al. [44] showed that the preparation based on biomass from Spirulina maxima microalga enriched with $\mathrm{Cu}(\mathrm{II})$ is a good alternative to inorganic salts as a source of micronutrients. The research was carried out on piglets divided into two groups (control and experimental). Both groups were fed with standard feeds prepared for each stage of the experiment (starter, grower, and finisher). The control group was fed with feed supplemented with traditional inorganic mineral salts and the experimental group was fed with the addition of S. maxima biomass enriched with $\mathrm{Cu}$ by biosorption. Because trace minerals are often oversupplied in feed preparations and trace minerals in the form of enriched S. maxima biomass are assumed to have increased bioavailability, diet levels of $\mathrm{Cu}$ in the first stage of experiments (the starter) were reduced by $50 \%$ for the experimental group compared to the control group. The results showed that pigs from the experimental group had a higher concentration of copper in the body by $30 \%$ compared to the control group. However, there was no impact on production results (average daily feed intake, average daily gain, and feed conversion ratio). In addition, it was found that copper concentration in the faeces in the experimental group was $60 \%$ lower than that in the control group. Biometallic feed additives can be proposed as reducing the amount of trace elements accumulated in the environment.

In an experiment conducted by Witkowska et al. [45], the fatteners diet contained soybean meal enriched with microelements $(\mathrm{Cu}(\mathrm{II}), \mathrm{Mn}(\mathrm{II}), \mathrm{FeII})$, and $\mathrm{Zn}(\mathrm{II}))$. This treatment resulted in an increase in daily gain of $15.2 \%$ with simultaneous reduction of feed intake by $19.9 \%$. The pigs were divided into three groups: a control group fed with fodders with the addition of inorganic salts, and two experimental groups, which were fed with the addition of biologically enriched soy meal, respectively. All compound feeds have been produced from the same components, and only different premixes were applied. In the first experimental group, the level of soybean meal in the feed was $1.7 \mathrm{~g} / \mathrm{kg}$ soya- $\mathrm{Cu}, 4.2 \mathrm{~g} / \mathrm{kg}$ soya-Fe, $3.4 \mathrm{~g} / \mathrm{kg}$ soya- $\mathrm{Mn}$, and 
$5.5 \mathrm{~g} / \mathrm{kg}$ soya-Zn. In the second experimental group, the level of soybean meal in the feed was $2.13 \mathrm{~g} / \mathrm{kg}$ soya-Cu, $5.25 \mathrm{~g} / \mathrm{kg}$ soya-Fe, $4.25 \mathrm{~g} / \mathrm{kg}$ soya-Mn, and $6.88 \mathrm{~g} / \mathrm{kg}$ soya-Zn. The first experimental group was given $100 \%$ of the demand for micronutrients, and the second group was given soy meal, which covered $125 \%$ of the demand. The use of soy-enriched additive resulted in increased slaughtering efficiency and increased carcass weight by $5 \%$. In meat from experimental groups, water retention was increased by $19 \%$, which provided better juiciness. Furthermore, a darker red meat color was observed. The iron content in the meat of the pigs of the first experimental group was increased by about $10 \%$, while in the second experimental group, the content of all microelements in meat increased by $4.3 \%$ to $20.3 \%$ compared to the control group.

Jiang et al. [46] investigated the effect of pig supplementation with sodium selenite in combination with soybean oil and the organic form of selenium in combination with soy oil or linseed oil. It was found that the feed with the addition of organic selenium and linseed oil increased the content of Se in the muscles to $54 \%$, doubled the content of omega-3 fatty acids, decreased the water loss in meat by 58-74\%, and increased tenderness. Calvo et al. [47] evaluated the effect of selenium supplementation (organic versus inorganic minerals) and organic selenium together with vitamin $\mathrm{E}$ on fatty acid composition and pork quality. It was found that meat of pigs fed organic selenium had higher vitamin E deposition, less water loss, higher stability against oxidation, higher concentration of Se, and higher content of free fatty acids compared to meat of pigs fed with the addition of inorganic selenium. However, studies carried out by Lisiak et al. [48] showed that the highest content of selenium is characterized by the muscles of pigs receiving selenium in an inorganic form.

The enrichment of beef with micronutrients through feed additives is more difficult than in the case of monogastric animals due to the lack of direct transfer of nutrients to the tissues. Some of the supplied elements are used by rumen microorganisms [1]. Red meat, due to the high biological value of protein (18-23\%), minerals, and vitamins, is perceived as an important part of a healthy and balanced diet of people [49]. Ranches et al. [50] conducted studies on the biofortification effect of selenium of hayfields and its effect on the measurement of Se in cows and calves. The experiment was conducted on weaned calves, pregnant cows, and newborn calves. The concentration of Se in the liver of calves and cows fed with Se hay was higher than in control animals (no Se added) or groups fed with sodium selenite. Calves born from cows fed biofortified hay had a higher concentration of Se in plasma than calves from other groups. Pereira et al. [51] analyzed the concentration of trace elements in cows: Holstein-Friesian (HF), Galician Blonde (GB), and GBxHF cross. The animals were kept under identical conditions and fed ad libitum with feed with the addition of trace elements. In samples of internal organs and muscles obtained after slaughter, the general concentration of trace elements was within the norms and did not differ between races. However, the exception was the concentration of copper, which exceeded the recommended level of human consumption by $90 \%$. In HF cows, the concentration of copper, iron, manganese, selenium, and zinc in muscles was significantly higher than that in the GB. These differences could be related to the variability in muscle mass and higher liver activity in HF (dairy) cattle than in GB (beef).

\section{Summary}

In recent years, more and more studies have been reported regarding the enrichment of food of animal origin with biologically active compounds. Scientists manage to produce eggs, milk, or meat enriched with ingredients such as polyunsaturated fatty acids, vitamins, or macro- and micronutrients. To date, many methods have been developed to enrich food in these ingredients; however, one of the cheapest and most effective is the use of feed additives. However, it should be remembered that in the case of this method, the selection of appropriate feed additives is extremely important. During many studies, it was shown that microelements in organic form can be better absorbed by animals, improving the quality of products obtained from them. However, it should be taken into account that the use of organic forms of micronutrients does not bring positive results. Sometimes, it turns out that inorganic forms are better absorbed, and the use of organic forms not only does not improve but sometimes it negatively affects the production parameters of farm animals. Therefore, despite many promising results, the study on the use of organic forms of micronutrients should be continued.

\section{Conflicts of Interest}

The authors declare that they have no conflicts of interest.

\section{Acknowledgments}

The study was cofinanced from the funds of the National Scientific Lead Center (KNOW) for the years 2014-2018 through the Wrocław Center of Biotechnology.

\section{References}

[1] M. Korczyński, R. Kupczyński, M. Świniarska, D. Konkol, and S. Opaliński, "Fortification of animals foodstuff," in Food Biofortification Technologies, A. Saeid, Ed., pp. 273-312, CRC Press, Boca Raton, FL, USA, 2017.

[2] International Feed Industry Federation, January 2018, http:// www.ifif.org/pages/t/Global+feed+production.

[3] The European Feed Manufacturers' Federation, January 2018, http://www.fefac.eu/files/69455.pdf.

[4] M. Korczyński and S. Opaliński, "Dodatki paszowe jako potencjalna perspektywa dla przemysłu paszowego," Przemyst Chemiczny, vol. 5, pp. 792-795, 2012, in Polish.

[5] M. Słupczyńska, D. Jamroz, J. Orda, and A. Wiliczkiewicz, "Effect of various sources and levels of iodine, as well as the kind of diet, on the performance of young laying hens, iodine accumulation in eggs, egg characteristics, and morphotic and biochemical indices in blond," Poultry Science, vol. 93, no. 10, pp. 2536-2547, 2014.

[6] M. B. Roberfroid, "Concepts and strategy of functional food science: the European perspective," American Journal of Clinical Nutrition, vol. 71, no. 6, pp. 1660S-1664S, 2000. 
[7] H. Grajeta, “Żywność funkcjonalna w profilaktyce chorób układu krążenia," Advances in Clinical Experimental Medicine, vol. 13, pp. 503-510, 2004.

[8] D. Jamroz, "Składniki mineralne," in Żywienie zwierzą $i$ paszoznawstwo. Tom 1. Fizjologiczne i biochemiczne podstawy żyienia zwierzat, (Wydanie 2 zmienione), D. Jamroz, Ed., pp. 62-91, Wydawnictwo Naukowe PWN SA, Warsaw, Poland, 2015, in Polish.

[9] K. Chojnacka, "Zastosowanie metody biosorpcji w wytwarzaniu żywności biofortyfikowanej w mikroelementy," Przemyst Chemiczny, vol. 90, no. 5, pp. 707-710, 2011, in Polish.

[10] B. Dolińska, S. Opaliński, M. Zieliński, K. Chojnacka, Z. Dobrzański, and F. Ryszka, "Iodine concentration in fodder influence the dynamics of iodine levels in hen's egg components," Biological Trace Element Research, vol. 144, no. 1-3, pp. 747-752, 2011.

[11] I. Michalak, K. Chojnacka, Z. Dobrzański et al., "Effect of macroalge enriched with microelements on egg quality parameters and mineral content of eggs, eggshell, blond, feathers and droppings," Journal of Animal Physiology and Animal Nutrition, vol. 95, no. 3, pp. 374-387, 2011.

[12] Z. Dobrzański, T. Trziszka, E. Herbut, J. Krawczyk, and P. Tronina, "Effect of humic preparations on productivity and quality traits of eggs from greenleg partridge hens," Annals of Animal Science, vol. 9, no. 2, pp. 165-174, 2009.

[13] Z. Dobrzański, B. Dolińska, K. Chojnacka, S. Opaliński, and F. Ryszka, "Znaczenie drożdży w żywieniu zwierząt gospodarskich," Acta Scientiarum Polonorum, vol. 5, no. 2, pp. 49-66, 2006.

[14] G. F. W. Haenlein and M. Anke, "Mineral and trace element research in goats: a review," Small Ruminant Research, vol. 95, no. 1, pp. 2-19, 2011.

[15] J. W. Fuquay, P. F. Fox, and P. L. H. McSweeney, Encyclopedia of Dairy Sciences, Elsevier, London, UK, 2nd edition, 2011.

[16] U. Santoso and Y. Fenita, "The effect of Sauropus androgynus leaf extract on performance, egg quality and chemical composition of eggs," Journal of the Indonesian Tropical Animal Agriculture, vol. 41, no. 3, pp. 125-134, 2016.

[17] Z. Witkowska, K. Chojnacka, M. Korczyński et al., "Soybean meal enriched witch microelements by biosorption-A new biological feed supplement for laying hens. Part I. Performance and egg traits," Food Chemistry, vol. 151, pp. 86-92, 2014.

[18] S. Smulikowska and A. Rutkowski, Poultry Feeding Standards, PAN, Jabłonna, Poland, 4th edition, 2005, in Polish.

[19] A. Saeid, K. Chojnacka, S. Opaliński, and M. Korczyński, "Biomass of Spirulina maxima enriched by biosorption process as a new feed supplement for laying hens," Algal Research, vol. 19, pp. 342-347, 2016.

[20] S. Opaliński, B. Dolińska, M. Korczyński, K. Chojnacka, Z. Dobrzański, and F. Ryszka, "Effect of iodine-enriched yeast supplementation of diet on performance of laying hens, egg traits, and egg iodine content," Poultry Science, vol. 91, no. 7, pp. 1627-1632, 2012.

[21] M. Abedini, F. Shariatmadari, M. A. Karimi Torshizi, and H. Ahmadi, "Effects of a dietary supplementation with zinc oxide nanoparticles, compared to zinc oxide and zinc methionine, on performance, egg quality, and zinc status of laying hens," Livestock Science, vol. 203, pp. 30-36, 2017.

[22] A. B. H. A. A. Magied, S. M. Osman, A. S. Omar, N. Y. AbdelMalak, and A. Nehad, "Effect of using different levels and sources of zinc in layer's diets on egg zinc enrichment," Egyptian Poultry Science Journal, vol. 34, no. 1, pp. 39-56, 2014.
[23] K. Venglovska, L. Gresakova, I. Placha, M. Ryzner, and K. Cobanova, "Effects of feed supplementation with manganese from its different sources on performance and egg parameters of laying hens," Czech Journal of Animal Science, vol. 59, no. 4, pp. 147-155, 2014.

[24] A. Brodacki, J. Batkowska, A. Stępniowska, E. Blicharska, and K. Drabik, "Quality and mineral composition of eggs from hens supplemented with copper-lysine chelate," Archives Animal Breeding, vol. 61, no. 1, pp. 109-113, 2018.

[25] V. Tufarelli, E. Ceci, and V. Laudadio, "2-hydroxy-4methylselenobutanoic acid as new organic selenium dietary supplement to produce selenium-enriched eggs," Biological Trace Element Research, vol. 171, no. 2, pp. 453-458, 2016.

[26] O. Chinrasri, P. Chantiratikul, S. Maneetong, S. Chookhampaeng, and A. Chantiratikul, "Productivity and selenium concentrations in egg and tissue of laying quails fed selenium from hydroponically produced selenium-enriched kale sprout (Brassica oleracea var. alboglabra L.)," Biological Trace Element Research, vol. 155, no. 3, pp. 381-386, 2013.

[27] V. Malathi, "Performance of dual purpose chicken supplemented with chromium yeast and nano chromium," Doctoral dissertation, Karnataka Veterinary, Animal and Fisheries Sciences University, Bidar, India, 2015.

[28] FAO, Food Outlook, Milk and Milk Product, FAO, Rome, Italy, 2016.

[29] T. Szulc, Tajemnice Mleka, UPWr, Wrocław, Poland, 2012, in Polish.

[30] W. Sobotka, M. Stanek, and E. Fiedorowicz, "Prozdrowotne właściwości tłuszczu mlekowego w zależności od rasy krów," Problemy Higieny i Epidemiologii, vol. 96, no. 4, pp. 808-811, 2015, in Polish.

[31] Š. Zamberlin, N. Antunac, J. Havranek, and D. Samaržija, "Mineral elements in milk and dairy products," Mljekarstvo/ Dairy, vol. 62, no. 2, 2012.

[32] Z. Witkowska, I. Michalak, M. Korczyński et al., "Biofortification of milk and cheese with microelements by dietary feed bio-preparations," Journal of Food Science and Technology, vol. 52, no. 10, pp. 6484-6492, 2015.

[33] A. Pechova, L. Sevcikova, L. Pavlata, and R. Dvorak, "The effect of various forms of selenium supplied to pregnant goats on selected blond parameters and on the concentration of Se in urine and blood of kids at the time of weaning," Veterinární Medicína, vol. 57, no. 8, pp. 394-403, 2012.

[34] M. P. Lyons, T. T. Papazyan, and P. F. Surai, "Selenium in food chain and animal nutrition: lessons from nature," AsianAustralasian Journal of Animal Sciences, vol. 20, no. 7, pp. 1135-1155, 2007.

[35] J. S. Osorio, E. Trevisi, C. Li, J. K. Drackley, M. T. Socha, and J. J. Loor, "Supplementing $\mathrm{Zn}, \mathrm{Mn}$, and $\mathrm{Cu}$ from amino acid complexes and Co from cobalt glucoheptonate during the peripartal period benefits postpartal cow performance and blond neutrophil function," Journal of Dairy Science, vol. 99, no. 3, pp. 1868-1883, 2016.

[36] I. Páleníková, K. Hauptmanová, E. Pitropovská et al., “Copper metabolism in goat-kid relationship at supplementation of inorganic and organic forms of copper," Czech Journal of Animal Science, vol. 59, no. 5, pp. 201-207, 2014.

[37] D Średnicka-Tober, M. Barański, C. Seal et al., "Composition differences between organic and conventional meat: a systematic literature review and meta-analysis," British Journal of Nutrition, vol. 115, no. 6, pp. 994-1011, 2016.

[38] G. Kralik and Z. Kralik, "Poultry products enriched with nutricines have beneficial effects on human health," Medicinski Glasnik, vol. 14, no. 1, pp. 1-7, 2017. 
[39] M. Lukić, Z. Pavlovski, and Z. Škrbić, "Mineral nutrition of modern poultry genotypes," Biotechnology in Animal Husbandry, vol. 25, no. 5-6, pp. 399-409, 2009.

[40] M. Sahraei, H. Janmmohamadi, A. Taghizadeh, G. A. Moghadam, and S. A. Rafat, "Estimation of the relative bioavailability of several zinc sources for broilers fed a conventional corn-soybean meal diet," Journal of Poultry Science, vol. 50, no. 1, pp. 53-59, 2013.

[41] A. Sobolev, B. Gutyj, N. Grynevych, V. Bilkevych, and Y. Mashkin, "Enrichment of meat products with selenium by its introduction to mixed feed compounds for birds," Regulatory Mechanisms in Biosystems, vol. 8, no. 3, pp. 417-422, 2017.

[42] J. L. Li, L. Zhang, Z. Y. Yang et al., "Effects of different selenium sources on growth performance, antioxidant capacity and meat quality of local Chinese Subei chickens," Biological Trace Element Research, vol. 181, no. 2, pp. 340-346, 2018.

[43] I. Michalak, K. Chojnacka, and D. Korniewicz, "New feed supplement from macroalgae as the dietary source of microelements for pigs," Open Chemistry, vol. 13, no. 1, pp. 1341-1352, 2015.

[44] A. Saeid, K. Chojnacka, M. Korczyński, D. Korniewicz, and Z. Dobrzański, "Biomass of Spirulina maxima enriched by biosorption process as a new feed supplement for swine," Journal of Applied Phycology, vol. 25, no. 2, pp. 667-675, 2013.

[45] Z. Witkowska, A. Saeid, M. Korczyński, Z. Dobrzański, and K. Chojnacka, "Biofortification of meat with microelements by biological dietary feed supplements," Journal of Nutrition and Food Sciences, vol. 4, no. 6, p. 311, 2014.

[46] J. Jiang, X. Tang, Y. Xue, G. Lin, and Y. L. Xiong, "Dietary linseed oil supplemented with organic selenium improved the fatty acid nutritional profile, muscular selenium deposition, water retention, and tenderness of fresh pork," Meat Science, vol. 131, pp. 99-106, 2017.

[47] L. Calvo, J. Segura, F. Toldra et al., "Meat quality, free fatty acid concentration, and oxidative stability of pork from animals fed diets containing different sources of selenium," Food Science and Technology International, vol. 23, no. 8, pp. 716-728, 2017.

[48] D. Lisiak, P. Janiszewski, T. Blicharski, K. Borzuta, and E. Grześkowiak, "Effect of selenium supplementation in pig feed on slaughter value and physicochemical and sensory characteristics of meat," Annals of Animal Science, vol. 14, no. 1, pp. 213-222, 2014.

[49] K. D. Cashman and A. Hayes, "Red meat's role in addressing 'nutrients of public health concern," Meat Science, vol. 132, pp. 196-203, 2017.

[50] J. Ranches, J. M. Vendramini, and J. D. Arthington, "Effects of selenium biofortification of hayfields on measures of selenium status in cows and calves consuming these forages," Journal of Animal Science, vol. 95, no. 1, pp. 120-128, 2017.

[51] V. Pereira, P. Carbajales, M. López-Alonso, and M. Miranda, "Trace element concentration in beef cattle related to the breed aptitude," Biological Trace Element Research, 2018. 

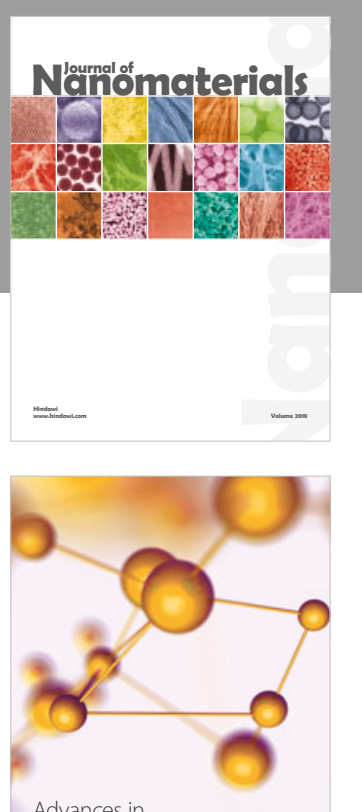

Physical Chemistry
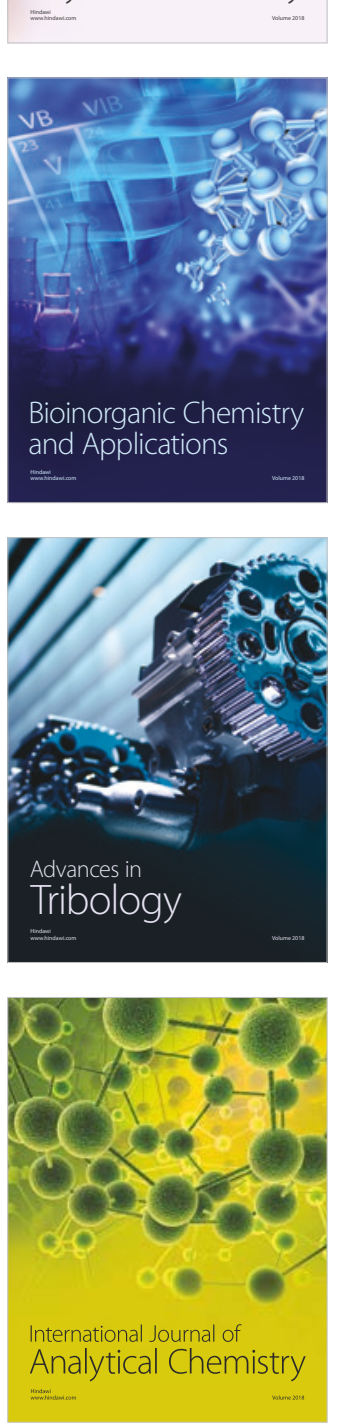

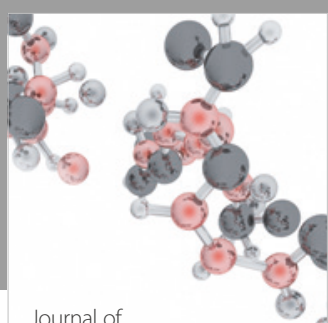

Analytical Methods

in Chemistry

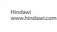

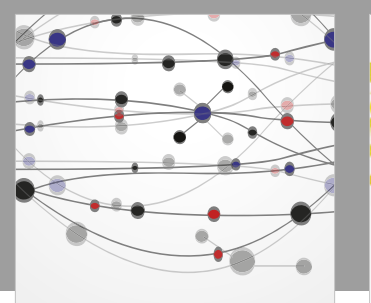

The Scientific World Journal

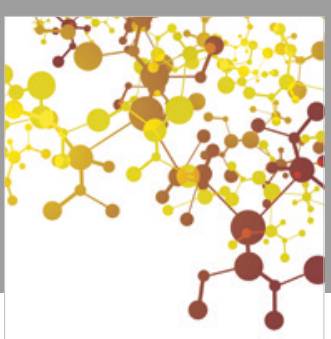

Journal of

Applied Chemistry
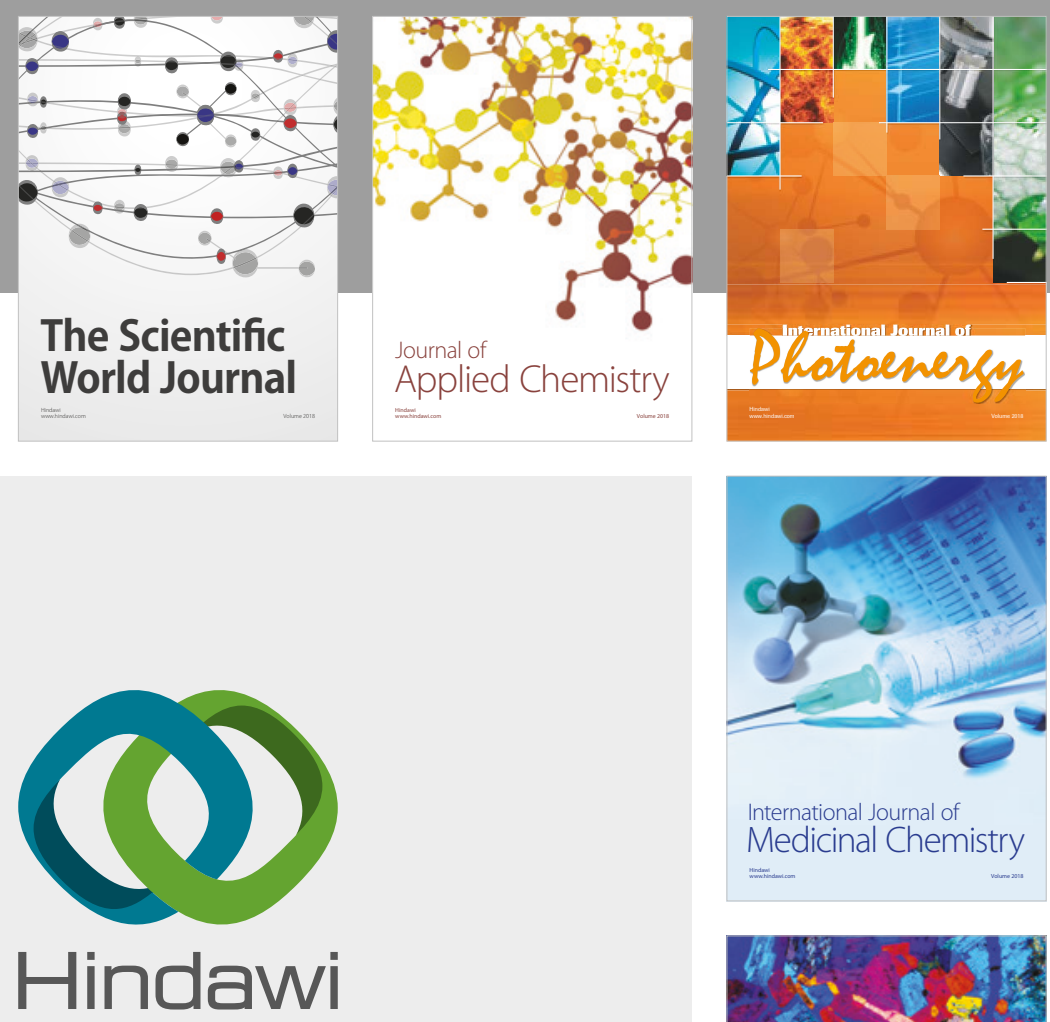

Submit your manuscripts at

www.hindawi.com
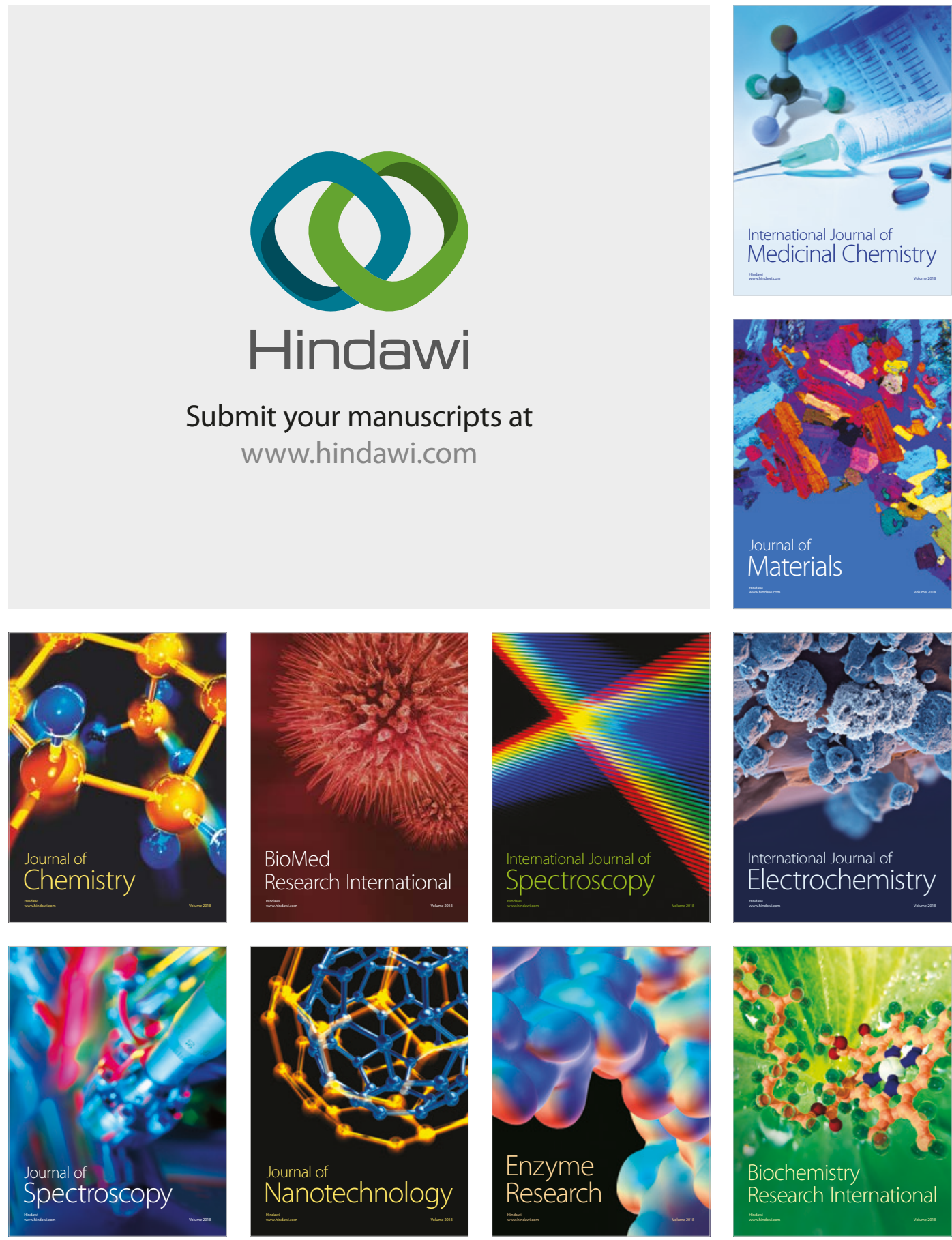
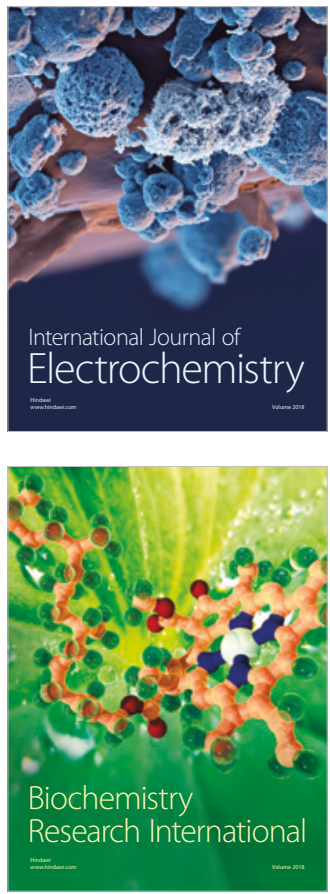